Original Paper http://ajol.info/index.php/ijbcs $\quad$ http://indexmedicus.afro.who.int

\title{
Effectiveness of probiotic feed ingredient on the growth performance of broiler
}

\author{
A.F. GNIKPO ${ }^{1}$, C.A.A.M. CHRYSOSTOME ${ }^{1}$, F.M. HOUNDONOUGBO ${ }^{1 *}$, \\ A.D. ADENILE ${ }^{2}$, T.J. DOUGNON ${ }^{3}$ and J.T.C. CODJIA ${ }^{4}$ \\ ${ }^{I}$ Poultry Research Laboratory and Zoo-Economics, Faculty of Agricultural Sciences, \\ University of Abomey-Calavi, Benin. \\ ${ }^{2}$ Laboratory of Ethnopharmacology and Animal Health, Faculty of Agricultural Sciences, \\ University of Abomey -Calavi, Benin. \\ ${ }^{3}$ Research Laboratory in Applied Biology, University of Abomey-Calavi, Benin. \\ ${ }^{4}$ Laboratoire de recherche en Ecologie Animale et Zoogéographie, \\ Faculté des Sciences Agronomiques, Université d'Abomey-Calavi, 01 BP 526 Cotonou, Bénin. \\ *Corresponding author; E-mail: fredericmh@gmail.com ; Phone: (229) $95968136 / 96142965$.
}

\begin{abstract}
The use of antibiotics in human or veterinary therapy is followed by the appearance of bacteria resistance to these antibiotics. This is a serious problem because of the direct impact on therapeutic possibilities. This study aimed at evaluating the efficiency of a probiotic feed ingredient (Starter) on the growth performance of broiler (Hubbard) to allow a reduction of the use of antibiotics. The experimental design consists of four treatments with three replications: diets with $0 \%, 1.5 \%, 3 \%$ and $4.5 \%$ of the probiotic feed ingredient. Each replication consists of 18 broilers with an average live body weight of $43.04 \pm 6.38 \mathrm{~g}$. After seven (7) weeks of trial, chickens receiving the treatment .T1.5 had the best growth with an average weight of $984.22 \pm 249.2 \mathrm{~g}$, but with no significant difference $(\mathrm{P}>0.05)$. In this treatment, their feed intake was the highest ( $51.38 \mathrm{~g} / \mathrm{bird} / \mathrm{day})$ while the feed conversion rate turned out to be the lowest $(6.67 \mathrm{~g}$ feed/g Live body weight). The highest value of carcass yield $(76.1 \%)$ and sternum proportion $(5.54 \%)$ were obtained in treatment T3. From the above results, we can state that the probiotic feed ingredient included at $1.5 \%$ and $3 \%$ improved growth performance of broilers. It could help to significantly improve the production performance of broilers if its probiotics properties are enhanced.
\end{abstract}

(C) 2016 International Formulae Group. All rights reserved.

Keywords: Broiler, feeding, tchoukoutou, kpètè-kpètè, carcass yield.

\section{INTRODUCTION}

To meet the needs of the growing population, the use of drugs to improve animal performance became a common practice. The annual quantities of antibiotics and coccidiostats additives used in animal feed in France are estimated at 1,270.06 tons in 2004 (AFSSA, 2006). Despite this large quantity of antibiotic used, the residue prevalence of veterinary drugs in feed of animal origin is less than $1 \%$ in Europe, while it reached $94 \%$ in some countries in Africa 
(Mensah, 2014). Surveys conducted in Benin, Togo, Mali, Mauritania, Cameroon and Chad, have revealed that nearly $61 \%$ of veterinary drugs do not comply with the norm (Abiola, 2001, 2002, 2005). Microbiological and physico-chemical analyses of 37 liver or gizzard samples collected in the regions of Dakar and Thies (Senegal), revealed that $14 \%$ of the samples contained residues of tetracyclines, $8 \%$ of sulfonamide residues, $41 \%$ of nitrofuran residues and $5 \%$ of chloramphenicol (gizzards only) (Abiola et al., 2005; Alambedji, 2008). These residues contribute to the development of resistance to antibiotics in bacteria (Chauvin et al., 2002) and therefore constitute a very serious problem because of the direct impact on therapeutic possibilities (Stoltz, 2008). To avoid the harmful effects of these drugs, they can be substituted with natural products, composed with probiotic bacteria, such as

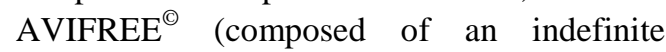
culture from chickens Specific Pathogen Free), AVIGUARD ${ }^{\odot} \quad$ (indefinite culture, mixed and then lyophilized from cecal contents of adult chickens) BROILACT ${ }^{\odot}$ (lyophilized preparation containing 32 different types of anaerobic bacteria of which 22 from 5 different genres and 10 facultative anaerobic from 3 different genres), PREEMPT $^{\odot}$ (cecal contents of 10 weeks chickens whose culture is held at low $\mathrm{pH}$ to select strict and facultative anaerobic bacteria) (Castagnos, 2003).

The term probiotic, according to Gilliland et al. (2001) is a relatively new word meaning "for life" and it is currently used to name bacteria associated with beneficial effects for humans and animals. In Benin, the residue of a traditional beer (tchoukoutou) has been used in experimental trials as alternative of antibiotics (Houndonougbo et al., 2011). Thus, the better valorization of the potential of traditional beer (tchoukoutou) residue and lactic acid bacteria which it contained could help reducing the pressure on the use of antibiotics and hence reduce the rate of bacterial resistance to antibiotics. From the microbiological properties of "tchoukoutou" residues and ferment of this traditional beer; a standard ferment is developed. Gilliland et al. (2001) recommended the in vitro and in vivo test method before the establishment of a health benefit to confer to probiotic microorganisms. According to N'Tcha et al. (2016), five species of lactic acid bacteria isolated from "kpete-kpete" samples: have antimicrobial activity against reference strains; are resistant to some conventional antibiotics, are tolerant to gastric acidity and resistant to bile salts, are resistant to stomachduodenal stimulus; can adhere to epithelial cells; have the acceptable hydrophobicity percentage; have acidification power, have proteolytic power and lipolytic power. That permits these authors to indicate that these species from "kpete-kpete" are probiotics and can be used to focus on food ingredients with probiotic property. In vitro inhibition tests of extracts from this standard ferment of the sorghum beer "tchoukoutou" showed a strong antibiotic activity against pathogenic strains resistant to antibiotics such as methicillin (Kayodé et al., 2012). The second stage is the in vivo tests. Thus, we do not know in vivo effects of this standard ferment on the performance of domestic animals. The objective of this work was to continue the in vivo tests, by evaluating the effects of standard ferment of the sorghum beer "tchoukoutou" used as probiotic feed ingredient on the performance and carcass yield of broilers.

\section{MATERIALS AND METHODS \\ Probiotic feed ingredient}

The feed ingredient used was called probiotic due to the multiple probiotic properties of lactic acid bacteria it contained through "kpètè-kpètè", the traditional beer's ferment (N'Tcha et al., 2016). The probiotic feed ingredient (Table 2) used was a stabilized product of sorghum flour and the traditional ferment "kpètè-kpètè" (Table 2) which is made from a previous processing of sorghum beer "tchoukoutou". The production of probiotic feed ingredient followed the method described by Deh (2009). It consisted of 
decorticating the sorghum grain and grinding it. The semi-solid paste outcome of humidification of dry sorghum flour was pasteurized and inoculated with $10 \%$ of "kpètè-kpètè". The inoculated paste was fermented for $24 \mathrm{~h}$. It was then sieved and collected into clod. These clods were dried in an oven at $43{ }^{\circ} \mathrm{C}$ for 24 hours and gave the granules of probiotic feed ingredient used.

\section{Experimental design}

Two types of materials were used, day old chicks (Hubbard) and the formulated diets (Table 1) containing the probiotic feed ingredient. The experimental design was a randomized complete block with four treatments and three repetitions: a control diet (T0), which was the formulated feed without probiotic feed ingredient and three experimental diets. Experimental diets correspond to T1.5, T3 and T4.5 which were the control diet supplemented respectively with $1.5 \%, 3 \%$ and $4.5 \%$ of probiotic feed ingredient. A total of 216 chicks having 43.04 $\pm 6.38 \mathrm{~g}$ were divided in 12 replications. Each dietary treatment was fed to 3 replications of 18 chicks each during phase $1\left(1^{\text {st }}\right.$ to $21^{\text {th }}$ day; 23 chicks $\left./ \mathrm{m}^{2}\right)$ and phase $2\left(22^{\text {nd }}\right.$ to $42^{\text {th }}$ day; 11 chickens $/ \mathrm{m}^{2}$ ). Veterinary treatment was limited to vaccination against Newcastle, Goumboro diseases followed by a vitamin intake, diuretic and treatment against worms. No antibacterial and anticoccidial treatment was done.

\section{Statistical analysis}

Results were expressed as mean \pm standard deviation. Data were analyzed with $\mathrm{R}$ software through Analysis of variance (ANOVA). The evaluated effect was the rate of the supplemented probiotic feed ingredient. Probabilities $\mathrm{p} \leq 0.05$ were considered statistically significant while those between 0.10 and 0.05 were considered as trends in meaning. When there was significant difference, the test of Student Newman Keuls was carried out to identify treatment with significant effects.

\section{RESULTS}

Feed intake

Feed intake issues have increasingly evolved and were standardized from the $1^{\text {st }}$ to the $5^{\text {th }}$ week with approximately 18 to 69 $\mathrm{g} /$ subject/day. It remained stationary for chickens fed T1.5 and T4.5 while it decreased for chickens in $\mathrm{T} 0$ and $\mathrm{T} 3$ from the $5^{\text {th }}$ to the $7^{\text {th }}$ week. Chickens of the T0 got the lowest feed intake compared to those of other treatments while chicken in T1.5 had the highest feed intake (Table 3). However, chickens' feed intake has not varied significantly according to the dietary treatment.

\section{Weight gain and growth}

The growth curves (Figure 1) show that the dietary treatments had no effect on the growth of the broilers during the 4 first weeks. But, from the $5^{\text {th }}$ to the $7^{\text {th }}$ week, a difference was observed among the couple of treatments T1.5, T3 and treatments T0, T4.5. The treatments $\mathrm{T} 1.5$ and $\mathrm{T} 3$ showed a better performance. At 7 weeks, chickens in T1.5 and T3 have respectively gained an average weight of $984.22 \pm 249.2 \mathrm{~g}$ and $956.44 \pm$ $226.2 \mathrm{~g}$. These weights are higher than those of chickens in T0 and T4.5 (respectively 904.3 $\pm 216.4 \mathrm{~g}$ and $879.2 \pm 270.1 \mathrm{~g})$ with no significant difference $(\mathrm{P}=0.255)$. The chicken fed with control diet T0 could reach the average daily weight gain peak earlier in the $5^{\text {th }}$ week, while the chicken fed with T1.5, T3 and T4.5 reached this peak in the $6^{\text {th }}$ week. The higher average daily weight gain was recorded in T1.5 (20.19 g), T3 (20.04 g) (Figure 2).

\section{Feed Conversion Ratio}

Feed conversion ratio (FCR) varied from 2 to $3 \mathrm{~g}$ of feed/g body live weight. The highest values were recorded in treatment T4.5. FCR in T0 was the lowest between the $2^{\text {nd }}$ and the $5^{\text {th }}$ week. But between the $6^{\text {th }}$ and the $7^{\text {th }}$ week, the FCR in T0 increased. In T1.5 and T3, the variation of FCR was similar between the $6^{\text {th }}$ and the $7^{\text {th }}$ week (Table 4). It has varied according to the chickens' growth 
phases. At starter phase ( $1^{\text {st }}$ to $3^{\text {rd }}$ week), the FCR of chickens fed the supplemented diets was higher than that of chickens in control diet. Thus, from $4^{\text {th }}$ to $5^{\text {th }}$ week, the valorisation of supplemented feeds has not been better than that of the control feed even if there were more consumed over the period.

\section{Carcass characteristics}

The most important carcass yield $(76.10 \%)$ and sternum proportion $(5.54 \%)$ were recorded in $\mathrm{T} 3$ with no significant difference $(\mathrm{P}>0.05)$. The best gizzard proportion was in T0 (Table 5). Treatment T1.5 and T4.5 were less effective than the control diet for carcass yield, gizzard and sternum proportions.

Table 1: Ingredients composition of formulated feed.

\begin{tabular}{|c|c|c|}
\hline Feed stuffs & Composition Phase 1 (\%) & Composition Phase $2(\%)$ \\
\hline Maize & 58,3 & 59,6 \\
\hline Wheat bran & 3 & 5 \\
\hline Soyabean meal & 30.2 & 25 \\
\hline Cottonseed meal & 4 & 6 \\
\hline Palm oil & 1 & 1 \\
\hline Oyster shell & 1.8 & 1.8 \\
\hline Lysine & 0.2 & 0.1 \\
\hline Bicalcic Phosphate & 1 & 1 \\
\hline Salt & 0.3 & 0.3 \\
\hline Premix for broiler & 0.2 & 0.2 \\
\hline Total & 100 & 100 \\
\hline \multicolumn{3}{|c|}{$\begin{array}{l}\text { NB: The overall composition of sorghum grain, in \% of dry matter, used in the manufacture of probiotic feed ingredient } \\
65.3 \text { to } 81 \text { for Starch; } 8.1 \text { to } 16.8 \text { for Protein; } 1.4 \text { to } 6.2 \text { for Fat; } 0.4 \text { to } 7.3 \text { for Total fiber depending on Rooney and Serna } \\
\text { Salvador (2000). }\end{array}$} \\
\hline \multicolumn{3}{|c|}{$\begin{array}{l}\text { Table 2: Chemical and microbiological composition of the probiotic feed ingredient and "kpètè } \\
\text { kpètè". }\end{array}$} \\
\hline Variables & $\begin{array}{c}\text { Probiotic feed ingredient } \\
\text { (Djegui, 2012) }\end{array}$ & $\begin{array}{c}\text { Kpètè-kpètè } \\
\text { (Hounhouigan, 2007) } \\
\end{array}$ \\
\hline Dry matter (\%) & $84,39 \pm 0,99$ & 10,7 \\
\hline $\mathrm{pH}$ & $4,15 \pm 0,09$ & 3,4 \\
\hline Titrable acidity & - & 0,8 \\
\hline Lactic acid bacteria (Logcfu/g) & $7,95 \pm 0,76$ & $8,35 \pm 0,10$ \\
\hline Yeasts (Log cfu/g) & $7,6 \pm 0,10$ & $8,26 \pm 0,26$ \\
\hline
\end{tabular}

Table 3: Daily feed intake $(\mathrm{g})$ of broilers supplemented with a probiotic feed ingredient.

\begin{tabular}{lccccc}
\hline & T0 & T1.5 & T3 & T4.5 & P \\
\hline Phase 1 & $30,53 \pm 1,46$ & $32,40 \pm 0,89$ & $31,83 \pm 0,77$ & $31,99 \pm 1,47$ & 0,32 \\
Phase 2 & $61,98 \pm 4,26$ & $65,62 \pm 6,80$ & $63,48 \pm 3,15$ & $65,03 \pm 5,10$ & 0,81 \\
Overall phases & $48,50 \pm 3,05$ & $51,38 \pm 4,26$ & $49,91 \pm 2,10$ & $50,87 \pm 3,45$ & 0,73 \\
\hline
\end{tabular}


Table 4: Feed conversion ratio of broilers supplemented with a probiotic feed ingredient.

\begin{tabular}{lccccc}
\hline & T0 & T1.5 & T3 & T4.5 & P \\
\hline Phase 1 & $2,42 \pm 0,26$ & $2,56 \pm 0,18$ & $2,53 \pm 0,06$ & $2,55 \pm 0,27$ & 0,82 \\
Phase 2 & $2,92 \pm 0,30$ & $2,70 \pm 0,06$ & $2,74 \pm 0,02$ & $3,17 \pm 0,11$ & 0,03 \\
Overall phases & $2,75 \pm 0,18$ & $2,66 \pm 0,05$ & $2,68 \pm 0,03$ & $2,97 \pm 0,07$ & 0,02 \\
\hline
\end{tabular}

Table 5: Carcass yield, sternum and gizzard proportion following treatments.

\begin{tabular}{lccccc}
\hline & T0 & T1.5 & T3 & T4.5 & P \\
\hline Carcass yield (\%) & $73.34 \pm 0.78$ & $72.40 \pm 2.33$ & $76.10 \pm 6.04$ & $70.67 \pm 4.98$ & 0.12 \\
Guizard proportion $(\%)$ & $2.84 \pm 0.41$ & $2.72 \pm 0.29$ & $2.69 \pm 0.56$ & $2.64 \pm 0.48$ & 0.86 \\
Sternum proportion $(\%)$ & $5.46 \pm 0.97$ & $4.96 \pm 1.25$ & $5.54 \pm 0.59$ & $5.28 \pm 0.79$ & 0.66 \\
\hline
\end{tabular}

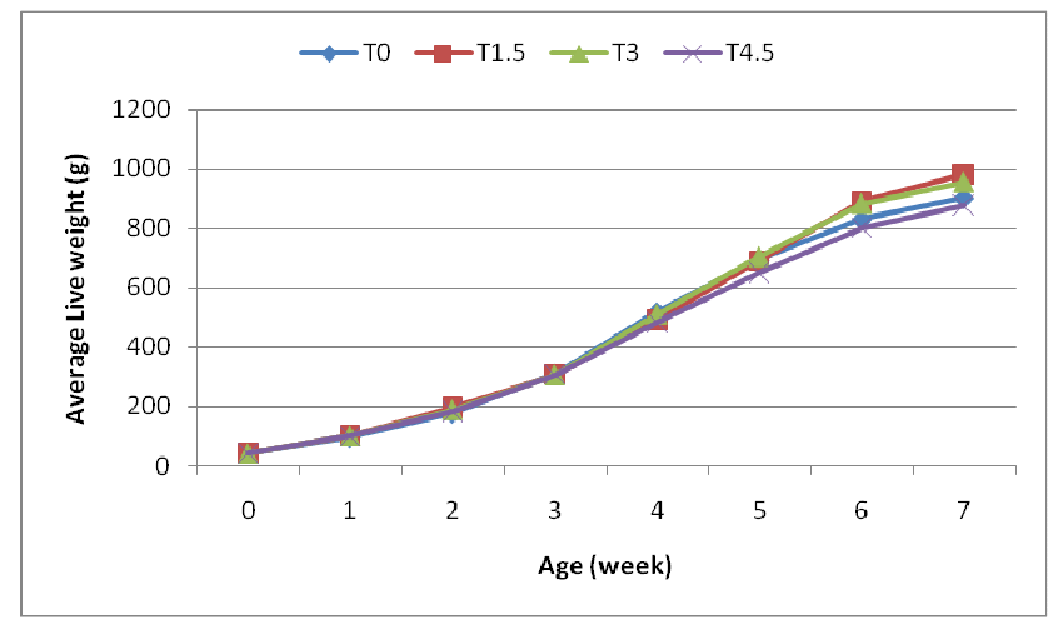

Figure 1: Growth curves of broilers supplemented with a probiotic feed ingredient.

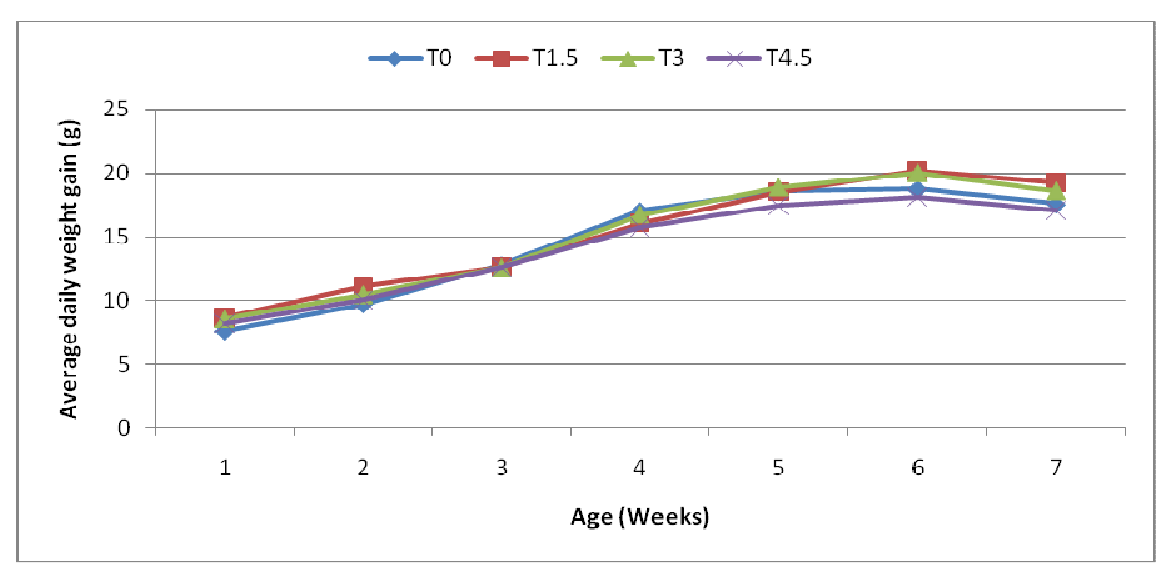

Figure 2: Daily weight gain curves of broilers supplemented with a probiotic feed ingredient. 


\section{DISCUSSION Feed intake}

In general, the feed intake of chickens that received the experimental diets is relatively more important. With $100 \mathrm{~g} /$ ton of commercial probiotic products containing Pediococcus acidilactici MA18/5M (Bactocell®), Chafai (2006) observed that the chicken feed intake was more important than that of the control group. The improvement of feed intake could be explained by improved palatability (Chafai, 2006). We could also think that supplemented feed with probiotic are more digested and eliminated relatively quickly. According to Houndonougbo et al. (2011), the increase in feed intake due to tchoukoutou residue was observed only in the starter phase $(2.39 \%)$. Such increase is $2 \%$ according to Gracia et al. (2009) at the same age (21 days). For both authors, the opposite effect is observed at the end of the growth phase. The result observed at the starter phase could be explained by the fact that the chickens' digestive microflora which is set in the chick phase is variously recruited. Indeed, in addition to the natural recruitment, the chicks treated with probiotic feed ingredient receive a supplement of bacteria and produce more quickly the balance of intestinal flora. This explains their high level of feed intake. Although the feed intake level does not imply the effectiveness of the feed, it helps assess the rearing conditions and also expect a better growth performance of broilers if the effectiveness of the feed is ensured.

\section{Weight gain and growth}

During the first four weeks, no significant difference was observed among the treatments $(\mathrm{P}=0.997)$. These results are contrary to those of Gracia et al. (2009) and Houndonougbo et al. (2011) that highlight a significant difference among diet containing the probiotic (Bacillus subtilis C-3102) or tchoukoutou residue and the control diet on day 21 chickens. Indeed, with the Bacillus subtilis C-3102, Gracia et al. (2009) observed that chickens fed with a diet containing the probiotic bacteria weighed $3.2 \%$ more than the control group at 21 days of age. This could be explained by the nature of the probiotic ingredient used. Gracia et al. (2009) have used a commercial product (Calsporin $\left.{ }^{\circledR}\right)$ developed with a specific probiotic bacterium (Bacillus subtilis C-3102). While the addition of the high concentration of Bacillus subtilis C-3102 in the commercial product to the feed $(50 \mathrm{~g}$ per ton of feed) is not noticeable on the organoleptic plan, on the contrary, the addition of probiotic feed ingredient in our test was very noticeable. This can be explained by the fact that the probiotic feed ingredient used, was added to the control diet up to $15000 \mathrm{~g}, 30000 \mathrm{~g}$ and $45000 \mathrm{~g}$ per ton of feed respectively for the treatments $\mathrm{T} 1.5, \mathrm{~T} 3$ and T4.5. This remarkable presence of probiotic feed ingredient in the diet may explain the fact that at the same age of 21 days, it is rather the control group that weighed about $0.74 \%$ more than the experimental groups with no significant difference $(\mathrm{P}=0.997)$. The probiotic feed ingredient would affect the valorization of the experimental diets at startup (phase 1).

At 42 days of age, the broilers fed T1.5 and T3 weighed $7.26 \%$ and $6.49 \%$ more than those in the control group with no significant difference (891.09 $\mathrm{g}$ and $884.66 \mathrm{~g}$ vs 830.76 $\mathrm{g} ; \mathrm{P}=0.248)$. That increase declined with $3 \%$ and $4.5 \%$ doses $(6.49 \%$ and - $3.36 \%$ respectively). Thus, the probiotic feed ingredient used, improves growth performance of the broilers at the grower phase. Compared to the results of Houndonougbo et al. (2011), the increase in weight was similar (7.08\%). Using Lactobacillus plantarum in broilers ISA15 diet, Tayeb et al. (2009) reported that the weight gain was almost $13 \%$ better at the $54^{\text {th }}$ day of age. These results show that both tchoukoutou residue used by Houndonougbo et al. (2011) and probiotic feed ingredient used in our experiment, though they can improve the growth performance of poultry, may be enhanced. Moreover, the optimal dose of the probiotic feed ingredient that produces the maximum growth performance in broiler chickens must be sought, since the doses 
higher than $1.5 \%$ were not only more effective but also have an effect inversely proportional to those doses.

\section{Feed Conversion Ratio (FCR)}

The results obtained are consistent with the observed weight gain with T1.5 and T3. Even if, during the starter phase, this probiotic ingredient-based feed was the most consumed, the end products of the digestion are not well valorised by chicks. A portion of the generated nutrients would be consumed by the digestive flora itself or eliminated by the process of digestion. The results could have been better if a heat treatment was done on the maize that represents more than half of the ration (Sawadogo et al., 2015). Because, this heat treatment induces changes in the composition of food and can even influence the minerals concentration of finished products (Hamunyari et al., 2014. Tshite et al., 2015). But, this effect would be contrary to that described by Martel et al. (1996) in case of the use of antibiotics as growth factor. According to Martel et al. (1996), in very low doses, antibiotics strongly inhibit the catabolism of urea and amino acids of bacteria of the intestinal flora. Thus, they increase the availability of nutrients and therefore give energy to the animal. Also, production of toxic molecules is reduced resulting in return to a decrease of the rate of renewal of the intestinal epithelium and further saving nutrients (Martel et al., 1996). In starter phase, probiotic bacteria in addition to the bacteria naturally brought by cereals and legumes of the ration (Tshite et al., 2015) would influence more negatively digestibility supplemented feeds.

Previous authors (Chafai, 2006; Gracia et al., 2009; Houndonougbo et al., 2011) did not observe any effect of starter or growth phase on feed conversion ratio (FCR). In this experiment, the FCR of chicken that received probiotic supplement is always the lowest. Between $5^{\text {th }}$ and $7^{\text {th }}$ week treatments with supplementation of $1.5 \%$ and $3 \%$ of probiotic feed ingredient induced low feed conversion ratio. In opposite to this, the dose of $4.5 \%$ maintained high FCR during this period $\left(5^{\text {th }}\right.$ and $7^{\text {th }}$ week). These opposite performances, on the one hand between $1.5 \%$ and $4.5 \%$ dose and on the other hand between $3 \%$ and $4.5 \%$ dose, confirmed as explained in the growth performance that probiotic feed ingredient would produce a regressive effect, inversely proportional to its rate of supplementation. We could explain the performance drop with the dose of $4.5 \%$, by the exceeding of optimal level of energy needed to chickens. Kuietche et al. (2014) made a similar observation about local barred chicks that have recorded higher feed conversion ratio when energy level in the ration is less than $2700 \mathrm{kcal} / \mathrm{kg}$ or greater than $2900 \mathrm{kcal} / \mathrm{kg}$. It could also be due to a decrease of digestibility of the feed due to sorghum used for the probiotic feed ingredient production.

\section{Carcass characteristics}

Houndonougbo et al. (2011) also obtained an improvement of carcass yield and the gizzard proportion with a tchoukoutou residue. The probiotic feed ingredient used in this study also gave a better carcass yield but a lower gizzard proportion. The average value of the recorded carcass yield $(73 \%)$ is similar to that observed by Karaoglu et al. (2005). They also note that with the treatment containing the highest dose $(0.2 \%)$ of yeast Saccharomyces cerevisiaea, the carcass yield was the lowest $(\mathrm{P}>0.05)$ compared to others treatments. This inspires that with high doses of probiotics, broiler performance begins with fall. Thus, an optimum must be determined as well as the negative phenomena engendered by overdoses of probiotic supplements. Zamanzad-Ghavidel et al. (2011) also observed differentiated performance based upon body parts of the chicken. While in the probiotic (Bacillus subtilis PB6, CloSTAT with the activity $\min .2 * 10^{7} \mathrm{CFU}^{*}{ }^{*}{ }^{1}$ ) supplemented groups at $0.05 \%$ dose, carcass percentage and net carcass yield did not show significant differences between the control group, there is significant differences $(\mathrm{P}<0.05)$ for breast percentage. The probiotic supplemented groups had a greater value. 


\section{Conclusion}

The probiotic feed ingredient used in broiler diet as additive improved their growth performance mainly at $1.5 \%$ and $3 \%$ of inclusion. In carcass characteristics field, the $3 \%$ dose conferred to broilers the best performance. Digestibility study will allow assessing the contributions of probiotic bacteria in the degradation of carbohydrate, the production of lactic acid in the crop or caeca. Attention should also be paid to the presence of pathogenic bacteria for health purpose.

\section{COMPETING INTERESTS}

The authors declare that they have no competing interests.

\section{AUTHORS' CONTRIBUTIONS}

AFG performed the trial and prepared the draft of this article; FMH followed the conduct of the study, assisted in the statistical analysis of data and improved article; CAAMC supervised the conduct of the test and improved article; ADA studied, validated the health component of the trial protocol, supervised its implementation and improved article; TJD studied and validated the health component of the trial protocol and JTCC contributed to the validation of the trial protocol.

\section{ACKNOWLEDGEMENTS}

The researchers would like to thank the Competitive Fund Program for Research (PFCR/UAC) University of Abomey-Calavi for its financial support for the realization of this work. Furthermore we are indebted to the Poultry Research Laboratory and ZooEconomics staff and all those who supported us with their materials and intellectual contribution to this work.

\section{REFERENCES}

Abiola FA, Diop MM, Teko-Agbo A, Delepine B, Biaou FC, Roudaut B, Gaudin V, Sanders P. 2005. Antibacterial residues in liver and gizzard of broilers in the regions of
Dakar and Thies (Senegal). Revue

Méd. Vét., 156(5): 264-268. www.revmedvet.com/2005/RMV156_ 264_268.pdf

Abiola FA. 2001. Quality anthelmintics and trypanocides in Cameroon (preliminary study by limited survey). In Expert report, Interstate School of Veterinary Sciences and Medicine (EISMV), Dakar, Senegal, p. 12.

Abiola FA. 2002. Quality anthelmintics and trypanocides in Mauritania (limited preliminary study by survey). In Expert report, Interstate School of Veterinary Sciences and Medicine (EISMV), Dakar, Senegal, p.13.

Abiola FA. 2005. Quality of veterinary drugs taken in Chad. In Expert report, Interstate School of Veterinary Sciences and Medicine (EISMV), Dakar, Senegal, p.13.

AFSSA (Agence Française de Sécurité Sanitaire des Aliments) 2006. Programme français de surveillance de l'antibiorésistance des bactéries d'origine animale. Rapport FARM 2003-2004 (French antimicrobial resistance monitoring in bacteria of animal origin), 66p.

Alambedji BR, Akakpo AJ, Teko-Agbo A, Chataigner B, Stevens A, Garin B. 2008. Residue monitoring: eg antibiotics in food in Senegal. OIE Conference on Veterinary Medicinal Products in Africa, Dakar, 25-27 March.

http://web.oie.int/fr/manifestations/VE TMED08/pdf_manuscrits/pdf_fran\%C 3\%A7ais/ALAMBEDJI_2603_Session 2_Legislation $\% 20 \& \% 20$ Control\%20A frica_Manuscript_fr.pdf

Castagnos S. 2003. Contribution to the study of the effectiveness of indefinite barrier flora $\left(\right.$ Aviguard $^{\circledR}$ ) against salmonella on chicken labels southwest. Veterinary doctor thesis, Paul Sabatier University, Toulouse, p. 79.

Chafai S. 2006. Effect of adding probiotics in diets on growth performance of broiler 
chickens. Master of Veterinary Science, Hadj Lakhdar El-Barna University, Algeria, p. 97.

Chauvin C, Madec F, Le Bouquin S, Sanders P. 2002. Pharmaco-epidemiological analysis of the use of antibiotics. Relationship with antibiotic resistance. Bull. Acad. Vet. France, 155: 277-282.

Deh DCSE. 2009. Development and optimization of the "kpete-kpete" stabilization technology: a ferment used for fermentation traditional opaque beer based sorghum (Sorghum bicolor Moench). Agronomist thesis, Abomey-Calavi University, AbomeyCalavi.

Djegui YK. 2012. Study of the effectiveness of a ferment based on "kpete-kpete" effects of the retention period, concentration and the fermentation time. Memory for graduation extensive studies, Abomey Calavi University, Abomey Calavi, p. 95.

Gilliland SE, Morelli L, Reid G. 2001. Health and Nutritional Properties of Probiotics in Food including Powder Milk with Live Lactic Acid Bacteria. Report of a Joint FAO/WHO Expert Consultation on Evaluation of Health and Nutritional Properties of Probiotics in Food Including Powder Milk with Live Lactic Acid Bacteria. www.who.int/foodsafety/fs.../en/probio tic_guidelines.pdf

Gracia M, Esteve-Garcia E, Cachaldora P, Marubashi T, McCartney E, Medel P, van der Aa A. 2009. Effectiveness of a probiotic based on Bacillus subtilis in broilers. Eighths Poultry Research Days. www.cabi.org/Uploads/animalscience/worldspoultry.../39_fpd2009_gracia.pdf

Hamunyari C, Tuarira M, Jefta T. 2014. Nutrient content of water spinach (Ipomoea aquatica) under different harvesting stages and preservation methods in Zimbabwe. Int. J. Biol. Chem. Sci., 8(3): 854-861. DOI: http://dx.doi.org/10.4314/ijbcs.v8i3.2
Houndonougbo MF, Chrysostome CAAM, Amoussa ZLAO. 2011. Tchoukoutou residue and yogurt as feed additives in broilers feed. Research Opinions in Animal \& Veterinary Sciences, 1(9): 597-600. www.roavs.com/archive/vol1-issue-9-2011.htm

Hounhouigan H. 2007. Evaluation and improvement of traditional production technology "kpete-kpete" leaven used for the fermentation of tchoukoutou. Agronomist thesis, Abomey-Calavi University, Abomey-Calavi.

Karaoglu M. and Durdag H. 2005. The Influence of Dietary Probiotic (Saccharomyces cerevisiae) Supplementation and Different Slaughter Age on the Performance, Slaughter and Carcass Properties of Broilers. International Journal of Poultry Science, 4(5): 309-316. www.pjbs.org/ijps/fin363.pdf

Kayodé APP, Deh DC, Baba-Moussa L, Kotchoni SO, Hounhouigan JD. 2012. Stabilization and preservation of probiotic properties of the traditional starter of African opaque sorghum beers. African Journal of Biothechnology, 11(30): 7725-7730. http://dx.doi.org/10.5897/AJB11.3231

Kuietche HM, Kana JR, Defang HF, Tadondjou CD, Yemdjie DDM, Teguia A. 2014. Effect of dietary energy level on growth performance and morphometric parameters of local barred chickens at the starter phase. Int. J. Biol. Chem. Sci., 8(3): 882-890. DOI: http://dx.doi.org/10.4314/ijbcs.v8i3.5

Martel JL, Chaslus-Dancla E, Coudert M, Lafont JP. 1996. Evolution of antibiotic susceptibility of bovine origin of Salmonella in France. Méd. Mal. Infect., 26(3): 415-419. DOI:10.1016/S0399-077X(96)80185-5

Mensah SEP, Koudandé OD, Sanders P, Laurentie M, Mensah GA, Abiola FA. 2014. Residues of antibiotics and animal products in Africa: public health risks. Rev. Sci. Tech. Off. Int. 
Epiz., 33(3). DOI : http://dx.doi.org/10.4314/ijbcs.v5i6.2

N'Tcha C, Haziz S, Agbobatinkpo P, VieiraDalodé G, Boya B, Codjia JTC, Kayodé PAP, Baba-Moussa L. 2016. Probiotic properties of lactic acid bacteria isolated from a beninese traditional beer's ferment. International Journal of Applied Biology and Pharmaceutical Technology, 7(2): 314-330. http://www.ijabpt.org/applied-

biology/probiotic-properties-of-lacticacid-bacteria-isolated-from-abeninesetraditional-beers-ferment.pdf

Rooney LW, Serna-Salvador SO. 2000. Sorghum in Handbook of Cereal Science and Technology (2nd edn), Kulp K, Ponte Jr. JG (eds). CRC Press.

Sawadogo II, Koala M, Dabire C, Ouattara LP, Bazie VBEJT, Hema A, Gnoula C, Pale E, Nebie RHC. 2015. Etude de l'influence des modes de transformation sur les teneurs en lycopène de quatre variétés de tomates de la région du nord du Burkina Faso. Int. J. Biol. Chem. Sci., 9(1): 362-370. http://dx.doi.org/10.4314/ijbcs.v9i1.31

Stoltz R. 2008. Antibiotic residues in food of animal origin: Evaluation and control this danger. Veterinary doctor thesis,
Claude-Bernard University, Lyon I, p. 152.

Tayeb I, Djamel B, Essaid L, Noureddine K. 2009. Probiotic Lactobacillus plantarum activity: study in broilers ISA 15. Poultry Research Days, 8: 312-315. www.journees-de-larecherche.org/Download.php?telecharg er=ALIMJRA2009.pdf

Tshite FN, Mulamba VT, Ndianabo MJT. 2015. Mise au point d'une farine précuite à base de maïs (Zea mays) et de soja (Glycine max) par la méthode traditionnelle. Int. J. Biol. Chem. Sci., 9(6): 2608-2622. DOI: http://dx.doi.org/10.4314/ijbcs.v9i6.8

Zamanzad-Ghavidel S, Adl KN, Sis NM, Aharizad S, Mirzaei-aghsaghali A, Mohammadian M, Siadati SA. 2011. Effects of lactobacillus-based probiotic on growth performance, mortality rate and carcass yield in broiler chickens. Annals of Biological Research, 2(2): 325-331.

http://scholarsresearchlibrary.com/arch ive.html 